Volume VI - Article 3

\title{
Security Interests in Patents and Patent Applications?
}

\author{
Pauline Stevens ${ }^{1}$
}

Fall 2005

\section{Copyright (C) University of Pittsburgh School of Law Journal of Technology Law and Policy}

There is a question mark in the title of this article because more questions than answers have been encountered in researching the topic. The relative certainty with which owners of furniture, equipment, accounts and most other personal property can obtain credit by granting a security in their property rapidly dissipates when the property in question is intellectual property. Owners of patents and other intellectual property find barriers to obtaining secured credit that are not faced by other property owners because there is a historical gap between the federal law protecting rights of intellectual property owners and state laws addressing secured transactions. The increasing importance of intellectual property to the economy of the United States (patent filings having increased by seventy percent since $1996^{2}$ raises the visibility of this gap and urges consideration of changes in law. This would permit owners of intellectual property access to the same

\footnotetext{
1 Copyright Reserved. Parts of this article are adapted from "The Intersection of Film Finance and Revised Article 9: A Mystery" appearing in the spring edition of the U.C.L.A. Entertainment Law Review (2002). While this article focuses on patents and patent applications, other forms of intellectual property are subject to the same issues. For general discussions of some of these issues, see materials cited in notes 33 and 46 infra.

2 Intellectual property constitutes the largest sector of the American economy, contributing five percent to the gross domestic product, and it continues to grow in importance generally. James E. Rogan, Address Before the Subcommittee on Courts, the Internet and Intellectual Property Committee on the Judiciary U.S. House of Representatives (April 11, 2002) available at http://www.uspto.gov/web/offices/com/speeches/househrg2002.htm, (On file with Pittsburgh Journal of Technology, Law and Policy).
} 
financing opportunities that are available to owners of other personal property. There seems to be no public policy that justifies the current situation.

Owners of most property who approach lenders for secured credit generally are moving in well-charted waters. Financial institutions routinely extend credit on the basis of collateral for any number of purposes. With sufficient collateral, a lender knows that, even if a debtor defaults, the lender can foreclose on the collateral and apply the proceeds of such foreclosure to repayment of the debt. The more confident a lender feels in the validity and enforceability of its security interest in the collateral, the better the credit terms available to a debtor. In fact, extending credit secured by property such as accounts receivable, bank deposits, and other tangible goods in accordance with the provisions of Article 9 ("Article 9") of the Uniform Commercial Code (the "UCC") is commonplace. The simple documentation and specific foreclosure processes available to a secured lender under Article 9 help debtors access credit that might not otherwise be available to them. A certain lack of compatibility between Article 9 and the federal patent laws found in 35 U.S.C. (the "Patent Act"), however, has prevented owners of patents and patent applications from capitalizing on those assets in the same fashion as owners of other, more mundane, assets.

This article first explains how Article 9 works for financing secured by most personal property. It then discusses how the Patent Act generally preempts state law and explores the ill-defined extent to which the Patent Act preempts Article 9. Finally, this article discusses different ways in which the Patent Act could be amended to facilitate financing secured by patents and patent applications. 


\section{Article 9 of the UCC.}

Article 9 provides a set of rules governing a variety of personal property interests.

Among other things, it addresses the steps necessary to perfect security interests, ${ }^{3}$ the duties of secured parties, the rights of third parties affected by secured transactions, the priority of interests in personal property, and the steps necessary to enforce security interests. Article 9 can govern security interests held by secured parties ${ }^{4}$ in goods, ${ }^{5}$ chattel paper, ${ }^{6}$ deposit accounts, ${ }^{7}$ health-care-insurance receivables ${ }^{8}$ and commercial tort

\footnotetext{
3 "Security interest" is defined, in part, in U.C.C. § 1-201(37) (2000) to be "an interest in personal property or fixtures that secures payment or performance of an obligation."

${ }^{4}$ U.C.C. § 9-102(a)(72) defines a "secured party" as “(A) a person in whose favor a security interest is created or provided for under a security agreement, whether or not any obligation to be secured is outstanding; (B) a person that holds an agricultural lien; (C) a consignor; (D) a person to which accounts, chattel paper, payment intangibles, or promissory notes have been sold; (E) a trustee, indenture trustee, agent, collateral agent, or other representative in whose favor a security interest or agricultural lien is created or provided for; or $(\mathrm{F})$ a person that holds a security interest [arising under other sections of the U.C.C.]."
}

5 U.C.C. § 9-102(a)(44) defines "goods" as "things that are movable when a security interest attaches. The term includes (i) fixtures, (ii) standing timber that is to be cut and removed under a conveyance or contract for sale, (iii) the unborn young of animals, (iv) crops grown, growing, or to be grown, even if the crops are produced on trees, vines, or bushes, and (v) manufactured homes. The term also includes a computer program embedded in goods and any supporting information provided in connection with a transaction relating to the program if (i) the program is associated with the goods in such a manner that it customarily is considered apart of the goods, or (ii) by becoming the owner of the goods, a person acquires a right to use the program in connection with the goods. The term does not include accounts, chattel paper, commercial tort claims, deposit accounts, documents, general intangibles, instruments, investment property, letter-of-credit rights, letters of credit, money or oil, gas, or other minerals before extraction."

${ }^{6}$ U.C.C. § 9-102(a)(11) defines "chattel paper" in part as "a record or records that evidence both a monetary obligation and a security interest in specific goods, a security interest in specific goods and software used in the goods, a security interest in specific good and license of software used in the goods, a lease of specific goods, or a lease of specific goods and license of software used in goods."

7 U.C.C. § 9-102(a)(29) defines a "deposit account" as "a demand, time, savings, passbook, or similar account maintained with a bank. The term does not include investment property or accounts evidenced by an instrument."

8 U.C.C. § 9-102(a)(46) defines a "health-care-insurance receivables" as "an interest in or claim under a policy of insurance which is a right to payment of a monetary obligation for health-care goods or services provided." 
claims. ${ }^{9}$ Article 9 also covers security interests generally, as well as sales of accounts ${ }^{10}$

and a number of other categories of transactions, including true consignments, ${ }^{11}$ certain

transactions with state and governmental units, sales of payment intangibles ${ }^{12}$ and sales

of promissory notes. ${ }^{13}$ Of course, there are limits to the categories of collateral covered

by Article $9 .^{14}$

Before a creditor has an enforceable security interest under Article 9, the security

9 U.C.C. § 9-102(a)(13) defines a "commercial tort claim" as "a claim arising in tort with respect to which: (A) the claimant is an organization; or (B) the claimant is an individual and the claim: (i) arose in the ordinary course of the claimant's business or profession; and (ii) does not include damages arising out of personal injury to or the death of an individual."

10 U.C.C. § 9-102(a)(2) defines an "account" as "a right to payment of a monetary obligation, whether or not earned by performance, (i) for property that has been or is to be sold, leased, licensed, assigned, or otherwise disposed of, (ii) for services rendered or to be rendered, (iii) for a policy of insurance issued or to be issued, (iv) for a secondary obligation incurred or to be incurred, (v) for energy provided or to be provided, (vi) for the use or hire of a vessel under a charter or other contract, (vii) arising out of the use of a credit or charge card or information contained on or for use with the card, or (viii) winnings in a lottery or other game of chance operated or sponsored by a State, governmental unit of a State, or person licensed or authorized to operate the game by a State or governmental unit of a State. The term includes health-careinsurance receivables. The term does not include (i) rights to payment evidenced by chattel paper or an instrument, (ii) commercial tort claims, (iii) deposit accounts, (iv) investment property, (v) letter-of-credit rights or letters of credit, or (vi) rights to payment for money or funds advanced or sold, other than rights arising out of the use of a credit or charge card or information contained on or for use with the card."

11 11 U.C.C. § 9-102(a)(20) defines a "consignment" as "a transaction, regardless of its form, in which a person delivers goods to a merchant for the purpose of sale and: (A) the merchant: (i) deals in goods of that kind under a name other than the name of the person making delivery; (ii) is not an auctioneer; and (iii) is not generally known by its creditors to be substantially engaged in selling the goods of others; (B) with respect to each delivery, the aggregate value of the goods is $\$ 1,000$ or more at the time of delivery; (C) the goods are not consumer goods immediately before delivery; and (D) the transaction does not create a security interest that secures an obligation."

12 U.C.C. § 9-102(a)(61) defines a "payment intangible" as "a general intangible under which the account debtor's principal obligation is a monetary obligation."

13 U.C.C. § 9-102(a)(65) defines a "promissory note" as "an instrument that evidences a promise to pay a monetary obligation, does not evidence an order to pay, and does not contain an acknowledgement by a bank that the bank has received for deposit a sum of money or funds."

14 U.C.C. § 9-109 (amended 2001). One of the most common types of collateral not covered by Revised Article 9 is insurance proceeds. U.C.C. § 9-109(d)(8) excludes from the scope of Revised Article 9 "transfer[s] of an interest in or an assignment of a claim under a policy of insurance, other than an assignment by or to a health-care provider of a health-care-insurance receivable." However, consistent with its prior version of Old Article 9, Section 9-109(d)(8) of the California Uniform Commercial Code does not exclude insurance from the scope of Revised Article 9. 
interest must "attach." Section 9-203 of Article 9 states that a security interest attaches ${ }^{15}$ when (1) value ${ }^{16}$ has been given to the debtor, (2) the debtor has rights in the collateral and (3) either (a) the collateral is in the possession or under the control of the secured party or (b) the debtor ${ }^{17}$ has signed a security agreement ${ }^{18}$ describing the collateral. ${ }^{19}$ Debtors generally may grant security interests in property not yet owned. ${ }^{20}$ Collateral not yet owned is frequently called "after acquired collateral."

Merely having an attached security interest will generally not give a secured creditor the most valuable rights available to it. A creditor's security interest that has attached but has not yet been "perfected" is subordinate to other creditors' perfected security interests and to the interests of persons who become lien creditors before the newly secured creditor perfects the security interest or files a financing statement, whichever comes first. ${ }^{21}$ Because a lien creditor is defined to include a trustee in a bankruptcy, a creditor's unperfected security interest is not only subordinate to the interests of lien creditors and perfected secured creditors, but also to the interests of a

15 Under U.C.C. § 9-203(a), “[a] security interest attaches to collateral when it becomes enforceable against the debtor with respect to the collateral ...."

16 U.C.C. $\S 1-201(44)$ states that a person gives "value" for rights if those rights are acquired either in return for a commitment, in satisfaction of a pre-existing claim, by accepting delivery or in return for consideration that otherwise would "support a simple contract."

17 "Debtor" is defined in U.C.C. $\S 9-102(\mathrm{a})(28)$ as "(A) a person having an interest, other than a security interest or other lien, in the collateral, whether or not the person is an obligor; (B) a seller of accounts, chattel paper, payment intangibles, or promissory notes; or (C) a consignee."

18 "Security Agreement" is defined in U.C.C. $\S 9-102(a)(73)$ as "an agreement that creates or provides for a security interest."

19 See U.C.C. § 9-203(b).

20 U.C.C. $\$ 9-204$ (a) provides that, except in the case of commercial tort claims and certain consumer goods, "a security agreement may create or provide for a security interest in after-acquired collateral."

21 U.C.C. $\S 9-317(a)(2)$ 
bankruptcy trustee. This fact is significant because under section 544(a)(1) of the United States Bankruptcy Code ${ }^{22}$ (the "Bankruptcy Code"), a bankruptcy trustee may void a transfer ${ }^{23}$ made by the debtor to the same extent that a hypothetical lien creditor could. To prevent a trustee, in his capacity as a hypothetical lien creditor, from voiding the transfer of collateral to a secured party, a secured party must "perfect" its security interest and obtain priority over lien creditors in accordance with Article 9. Once perfected, a security interest in collateral and, generally speaking, ${ }^{24}$ in proceeds ${ }^{25}$ of the collateral has priority over the interests of lien creditors, including bankruptcy trustees, of the debtor and secured parties that perfect security interests by filing subsequent financing statements. ${ }^{26}$

A creditor perfects its security interest as provided in Article 9 depending on the type of collateral involved. As a general rule, "a financing statement must be filed to

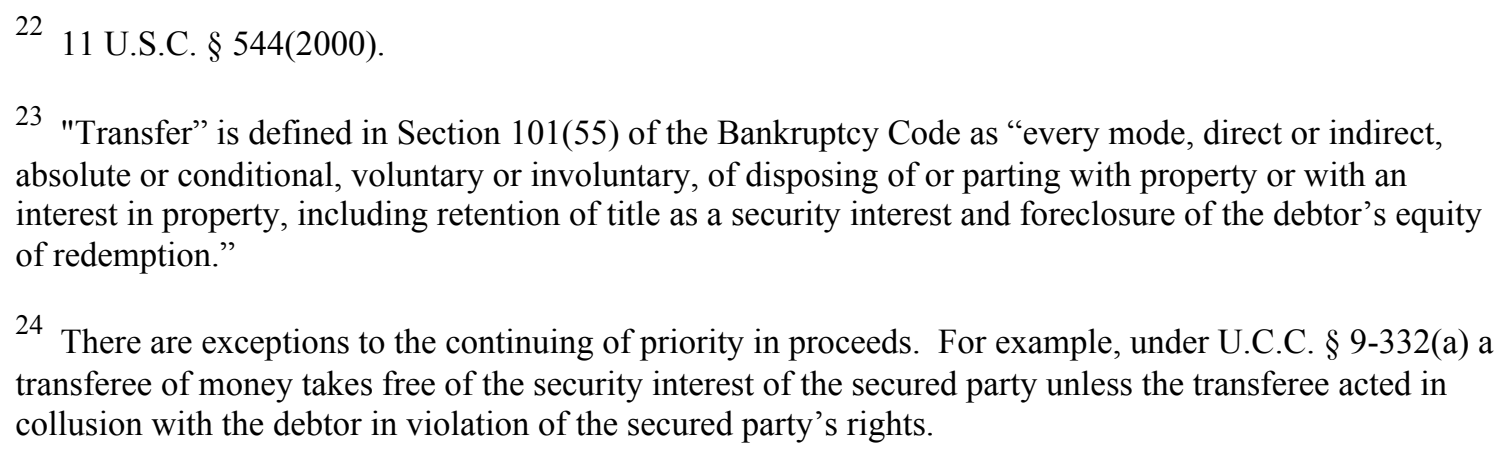
absolute or conditional, voluntary or involuntary, of disposing of or parting with property or with an interest in property, including retention of title as a security interest and foreclosure of the debtor's equity of redemption."

${ }^{24}$ There are exceptions to the continuing of priority in proceeds. For example, under U.C.C. § 9-332(a) a transferee of money takes free of the security interest of the secured party unless the transferee acted in collusion with the debtor in violation of the secured party's rights.

$25 \S 9-315(c)$ states that a "security interest in proceeds is a perfected security interest if the security interest in the original collateral was perfected." $\S 9-315(\mathrm{~d})$ sets forth the necessary conditions to maintain a perfected security interest in the proceeds within 21 days after the security interest attaches to the proceeds.

${ }^{26}$ What is called the first to file or perfect priority rule is embodied in $\S 9-322(a)$ of Revised Article 9. Exceptions to this rule are found in (1) § 9-322(d) which permits security interests perfected by possession or control in deposit accounts, investment property, letter-of-credit rights, chattel paper, instruments, and negotiable documents to have priority over an earlier filing and (2) § 9-322(a) which permits security interests in proceeds perfected by filing to have priority over an earlier perfected security interest in certain cases. 
perfect all security interests.... ${ }^{27}$ However, there are exceptions to this general filing rule for certain types of collateral that are perfected instead, by possession, control or as otherwise specifically provided. Where a financing statement is sufficient, the form, content and filing process required by Article 9 are simple: the form does not have to be signed by the debtor; the collateral description in the financing statement can be as simple as "all assets;" 28 and only one filing in the appropriate office ${ }^{29}$ is required. With few exceptions, the local law of the jurisdiction where the debtor is "located" governs perfection of security interests. ${ }^{30}$ According to section 9-307(e) of Article 9, a debtor that is a registered organization, ${ }^{31}$ such as a domestic corporation, limited liability company or limited partnership, is located in the state of its registration. ${ }^{32}$ Article 9 has a similarly simple filing procedure applicable to individuals and other types of organizations. For

\footnotetext{
27 Security interests in deposit accounts, electronic chattel paper, investment property and letter-of-credit rights may be perfected by "control" pursuant to U.C.C. § 9-314. Security interests in negotiable documents, goods, instruments, money and tangible chattel paper may be perfected by possession under $\S$ 9-313(a). Other exceptions to the perfection by filing rule include (1) under $\S 9-308(d)$, security interests in "supporting obligations" for the primary obligations which are perfected by perfecting a security interest in the primary collateral, (2) under § 9-308(f), security interests in "securities entitlements" held in "securities accounts" which are perfected by perfecting a security interest in the securities account, (3) pursuant to $\S 9-312$, security interests in goods in possession of a bailee that may be perfected by issuance of a document in the name of the secured party or notice to the bailee issuing non-negotiable documents covering the goods, (4) under $\S \S 9-312(\mathrm{e})$, (f), and (g), security interests in certificated securities, negotiable documents or instruments which are temporarily perfected, (5) under U.C.C. § 9-315, security interest that are temporarily perfected in proceeds, and (6) under $\S 9-316$, security interests that are temporarily perfected in collateral after change in the governing law.

${ }^{28}$ See § 9-504 (2), which states that a "financing statement sufficiently indicates the collateral that it covers if the financing statement provides... an indication that the financing statement covers all assets or all personal property."

29 See $§ 9-501$.

30 See $§ 9-301$.

31 "Registered organization" is defined in U.C.C. § 9-102(a)(70) as "an organization organized solely under the law of a single State or in the United States and as to which the State or the United States must maintain a public record showing the organization to have been organized."

32 See $\S 9-307(\mathrm{e})$.
} 
example, financing statements for foreign debtors are to be filed in the District of

Columbia, unless the jurisdiction in which the debtor is organized has a nonpossessory security interest filing system similar to Article $9 .{ }^{33}$

If a debtor defaults in payment of an obligation secured by a perfected security interest in collateral but does not file a bankruptcy case, Article 9 gives to the secured creditor the right, subject to any prior liens, to sell or otherwise dispose of the collateral and apply the proceeds to the secured obligations. ${ }^{34}$ Upon disposition of collateral, a good-faith transferee has all of the debtor's rights in the collateral. ${ }^{35}$ If the debtor files a case under the Bankruptcy Code, the secured creditor remains entitled to realize the benefit of its collateral, although foreclosure may be stayed. ${ }^{36}$ Because a secure creditor with a perfected security interest can expect to recover payment from collateral even if the debtor is insolvent, a secured party can afford to extend credit that an unsecured lender would be unwilling to make. ${ }^{37}$

\footnotetext{
${ }^{33}$ See $\S 9-307(c)$. While the ability to perfect a security interest in the assets of a foreign debtor by filing a financing statement in the United States has distinct advantages to secured creditors, there are significant attendant legal issues. See generally Neil. B. Cohen \& Edwin E. Smith, Symposium: International Secured Transactions and Revised U.C.C. Article 9, 74 ChI.-Kent L. ReV. 1191 (1999).

34 See $\S 9-601$ et seq.

35 U.C.C $\S 9-617$.

36 Under $\S 362$ of the United States Bankruptcy Code, with certain exceptions, upon the filing of a bankruptcy case, creditors are automatically stayed from taking actions against the debtor or collateral that is part of the bankruptcy estates. 11 U.S.C. $§ 362$ (2003).

37 The economic theory supporting secured lending has been summarized as follows: "(1) granting priority to a secured creditor increases its share of the debtor's assets in the event of default; (2) this reduces the amount of the loss that the secured creditor will suffer upon default; (3) this allows the secured creditor to charge a lower interest rate; and (4) the debtor can use the interest savings in a more productive fashion.” G. Ray Warner, The Anti-Bankruptcy Act: Revised Article 9 and Bankruptcy, 9 AM. BANKR. InST. L. REV. 3, 7 (2001)[hereinafter The Anti-Bankruptcy Act]. A contrary argument is that "(1) the grant of priority to the secured creditor reduces the unsecured creditors' share of the debtor's assets upon default; (2) this increases the amount of the loss that the secured creditors will suffer upon default; (3) this forces
} 
In sum, Article 9 sets out a series of rules intended to facilitate prompt, costeffective secured financing consistent with the needs of modern American businesses. As indicated above, however, ${ }^{38}$ Article 9 does not govern security interests in all types of personal property. The remainder of this article discusses why a creditor asked to extend credit secured by patents and patent applications must consider whether federal patent law addresses some or all of the issues embodied in Article 9.

\section{Patent Act Preemption of State Law Generally.}

The value of property rights in patents and patent applications derive, in part, from the protections accorded those assets by the federal Patent Act. Article 1, Section 8, Clause 8 of the U.S. Constitution gives Congress the power "to promote the progress of science and useful arts by securing for limited times to authors and inventors the exclusive right to their respective writings and discoveries. ${ }^{.39}$ Based on this power, Congress enacted the Patent Act which contains provisions protecting the rights of "[w]ho ever invests or discovers any new and useful process, machine, manufacture or

the unsecured creditors to charge higher interest rates; and (4) the debtor's extra interest expense on its unsecured credit exactly equals the interest savings on its secured credit." Id.

38

See U.C.C. § 9-109 (amended 2001).

39 The federal laws regarding copyrights contained in 17 U.S.C. have the same constitutional basis and protect "original works of authorship fixed in any tangible medium of expression." 17 U.S.C. § 102(a). Similarly, trademarks used in commerce that are federally registered are accorded federal protection by the Trademark Act of 1946, but the constitutional basis for those laws is found in the Commerce Clause in Article 1 of the U.S. Constitution authorizing Congress to regulate interstate and foreign commerce. This article does not address security interests in copyrights and trademarks, each of which has characteristics that are different from patents, but, generally speaking, the law of secured transactions as it relates to copyrights and trademarks creates issues for secured parties not unlike those faced in connection with security interests in patents. See generally, Alice Haemmerli, Insecurity Interests: Where Intellectual Property and Commercial Law Collide, 96 COLUM. L. REV. 1645, 1670 (1996). 
composition of matter, or any new and useful improvement thereof...."40 To obtain the protections accorded to the owner of a patent, including the right to sue for infringement, ${ }^{41}$ an inventor must apply for protection ${ }^{42}$ and satisfy any requirements imposed during the examination process. ${ }^{43}$ In the case of a utility patent, the invention for which protection is sought must be a novel and non-obvious invention. ${ }^{44}$ In the case of a plant patent, the plant must be a "distinct and new variety." patent, the design for an article must be "new, original and ornamental."

Under the Supremacy Clause, ${ }^{47}$ state laws that conflict with federal laws are given no effect. ${ }^{48}$ In examining preemption questions, the Supreme Court has balanced regard for the independent sovereign status of the states ${ }^{49}$ against the intent of Congress in enacting the federal legislation under consideration. ${ }^{50}$ Federal preemption has been said

4035 U.S.C. $\S 101(2003)$.

41 See Id. $\S 281$.

42 See Id. § 111.

43 See Id. $\S \S 131-135$.

${ }^{44} I d . \S 103$.

$45 I d . \S 161$.

${ }^{46} I d . \S 171$.

47 U.S. CONST. art. VI, cl. 2 (State laws are invalid if they interfere with, or are contrary to, the laws of Congress, made in pursuance of the Constitution.).

48 See, e.g., Cipollone v. Liggett Group, Inc., 505 U.S. 504, 516 (1992); Maryland v. Louisiana, 451 U.S. 725, 746 (1981); McCulloch v. Maryland, 17 U.S. (4 Wheat.) 316, 427 (1819).

49 See Medtronic, Inc. v. Lohr, 518 U.S. 470, 485 (1996); Rice v. Santa Fe Elevator Corp., 331 U.S. 218, 230 (1947).

50 See Medtronic, 518 U.S. at 485; Cipollone, 505 U.S. at 516; Retail Clerks Int'l Ass'n, Local 1625 v. Schermerhorn, 375 U.S. 96, 103 (1963). 
to arise in three distinct patterns -- field preemption, generally when legislation addresses an area of the law in a fashion such that the entire field is preempted, ${ }^{51}$ explicit preemption, when the language of the federal statute explicitly provides that it preempts state law, and conflict preemption, when compliance with state law specifically conflicts with compliance with federal law. ${ }^{52}$ There is no explicit preemption of state law by the Patent Act, thus courts have had to consider whether there is field or conflict preemption of state law by the Patent Act. ${ }^{54}$

The United States Supreme Court has considered the scope of federal preemption of state laws by the Patent Act and has made it clear that there are intersections between state law and the federal law where the state law is not preempted. ${ }^{55}$ In Kewanee Oil Co. v. Bicron Corp. ${ }^{56}$ ("Kewanee Oil"), the Supreme Court concluded that the goals of the Patent Act are to (1) give incentives for innovation by giving owners of patents the right to prevent others from using the patented material for a limited period of time and (2)

51 See Fidelity Fed. Sav. \& Loan Ass'n v. De La Cuesta, 458 U.S. 141, 153 (1982); Rice v. Santa Fe Elevator Corp., 331 U.S. 218, 230 (1947).

52 See English v. Gen. Elec. Co., 496 U.S. 72, 78-79 (1990).

53 See Fla. Lime \& Avocado Growers, Inc. v. Paul, 373 U.S. 132, 142-43 (1963); Hines v. Davidowitz, 312 U.S. 52, 66-67 (1941).

54 See Hunter Douglas, Inc. et al v. Harmonic Design, Inc., 153 F.3d 1318, 1332 (Fed. Cir. 1998) (holding that there was no field preemption of state unfair competition claims), cert. denied, 525 U.S. 1143, and overruled on other grounds by Midwest Indus., Inc. v. Karavan Trailers, Inc., 175 F.3d 1356 (Fed. Cir. 1999).

55 See Sears, Roebuck \& Co. v. Stiffel Co., 376 U.S. 225 (1964); Compco Corp. v. Day-Brite Lighting, Inc., 376 U.S. 234 (1964); Kewanee Oil Co. v. Bicron Corp., 416 U.S. 470 (1974); Aronson v. Quick Point Pencil Co., 440 U.S. 257 (1979).

56 Kewanee Oil Co. v. Bicron Corp., 416 U.S. 470, 480 (1974). 
encourage the disclosure of new ideas through the patenting process and by preventing states from removing from the public domain that which is already in the public domain. $^{57}$ When considering the question whether Ohio's trade secret law was preempted by federal patent law, the Kewanee Oil court examined whether such trade secret law violated any of these federal goals. The Court concluded that state trade secret laws that may encourage innovation are not preempted when preemption would not materially serve the goals of encouraging disclosure. While trade secret laws arguably discourage disclosure of ideas, the stronger legal rights accorded a patent holder (such as the right to exclude copying through reverse engineering) would necessarily encourage patenting property. Rather, trade secret laws protect rights that the Patent Act does not protect without having an anti-disclosure effect contrary to federal interests and, thus are not preempted by federal law.

As simple as the Kewqanee Oil analysis may sound, the Patent Act preemption doctrines received a difficult refinement in a case decided 15 years later. Revisiting the preemption doctrine in Bonito Boats, Inc. v. Thunder Craft Boats, Inc. ${ }^{58}$ ("Bonito Boats"), the Supreme Court considered whether enforcement of a Florida law prohibiting the duplication of an unpatented boat hull design through the use of a "direct molding

\footnotetext{
57 See Traffix Devices, Inc. v. Marketing Displays, Inc., 532 U.S. 23, 29 (2001) (citing Bonito Boats, Inc. v. Thunder Craft Boats, Inc., 489 U.S. 141, 160 (1989) for the proposition that "copying is not always discouraged or disfavored by the laws which preserve our competitive economy."); Pfaff v. Wells Elecs., Inc., 525 U.S. 55, 63 (1998) (citing Bonito Boats, 489 U.S. at 63 for the proposition that "the patent system represents a carefully crafted bargain that encourages both the creation and the public disclosure of new and useful advances in technology, in return for an exclusive monopoly for a limited period of time. The balance between the interest in motivating innovation and enlightenment by rewarding invention with patent protection on the one hand, and the interest in avoiding monopolies that unnecessarily stifle competition on the other, has been a feature of the federal patent laws since their inception.”). See generally Note, Patent License Assignment: Preemption, Gap Filling, and Default Rules, 77 B.U.L. Rev. 895 (1997).

${ }^{58}$ Bonito Boats, Inc. v. Thunder Craft Boats, Inc., 489 U.S. 141 (1989).
} 
process" was incompatible with the Patent Act. To determine whether state law was preempted, the Court looked at whether federal law makes clear the balance to be struck between encouraging the free exchange of information and still giving incentives to innovation. The Court said that the federal law addresses the balance to be struck between patent protection and free availability of information based on the fact that a patent expires after a number of years. As a result, states could not provide protection for property after expiration of a patent. Similarly, the fact that the Patent Act provides protections for a limited category of inventions was viewed as demonstrating that federal law strikes a balance in favor of free availability of information as to unpatented or unpatentable inventions. As a result, state laws prohibiting copying of unpatented inventions would remove from the public domain information that the patent laws intend to remain in the public domain.

On the other hand, the Bonito Boats case said that potentially patentable materials, such as trade dress and trade secrets, can be protected by state laws, because they address deceptive or tortious practices such as unfair competition. The Court said that state laws not inconsistent with keeping public information in the public domain would not be preempted when the state protections accorded to unpatented information are so much weaker than those accorded to patented inventions by federal law that the state law does not discourage use of the patenting process and the state law protects rights, such as the right of privacy, outside of the area of concern of federal laws. ${ }^{59}$ The Court concluded

59 While the court distinguished the Kewanee case on the basis of the weaker protections accorded to trade secrets by state law, it has been suggested that Kewanee simply reflected "the long and apparently harmonious coexistence of patent and trade secret law." Mark A. Lemley, Symposium: Beyond Preemption: The Law and Policy of Intellectual Property Licensing, 87 CAL. L. REV. 111, 139 n.118 (1999). 
that the law was preempted by federal law, because contrary to the balance of interests struck by the Patent Act, the Florida statute impaired free use of information by according permanent patent-like protection to unpatentable material while potentially encouraging inventive efforts to be guided in a fashion that was not reflective of federal law. The Court also found a basis for its opinion in the fact that enforcing state laws which provide patent-like protections would lead to confusion and encourage individual states to protect their favored businesses from competition.

\section{The Intersection of Article 9 and Patent Law.}

Section 9-109 of Article 9 acknowledges the preemptive effect of federal law and provides that Article 9 "does not apply to the extent that...a statute...of the United States preempts" its applicability. ${ }^{60}$ Article 9 also contemplates that there may be federal statutes that, while not entirely preempting Article 9, provide for federal systems that displace the general requirements of Article 9 that a financing statement be filed to perfect a security interest. ${ }^{61}$ Official Comment Number 2 to section 9-311 indicates that Article 9's requirements for perfecting a security interest are displaced by federal law only when federal law governs the priority of a security interest over a lien creditor. The Official Comment notes that the federal laws governing interests in aircraft are the type of federal statutes that will replace the filing requirements of Article 9 but that compliance with the Assignment of Claims Act will not. The Official Comments are

\footnotetext{
60 U.C.C. $\S 9-109$ (1999).

61 U.C.C. $\S 9-311 \mathrm{cmt} .2$ (1999).
} 
silent as to the Patent Act's effect on secured transactions. ${ }^{62}$ To apply the broad preemption principles enunciated in the Kewanee Oil and Bonito Boats cases to the question whether Article 9 is, or should be, preempted in whole or in part by the Patent Act, requires assessing whether there are elements of Article 9 that could be construed as inconsistent with the Patent Act's twin goals of encouraging both innovation and the disclosure of new ideas.

Broadly speaking, Article 9 contains rules establishing the relationship between (1) a secured party and its debtor, (2) a secured party and lien creditors, (3) multiple secured parties of the same debtor, (4) a secured party and transferees of property [its collateral], and (5) a secured party and licensees (and lessees) of property [its collateral]. As a general matter, the mere creation, or even perfection, of a security interest in patents would not seem to run afoul of fundamental Patent Act principles. However, enforcement of a security interest by transferring ownership of a patent interest without the consent of the owner arguably affects its incentives to encourage innovation. While the Supreme Court has not yet spoken on these issues, there are a number of cases that provide some general guidance on the issue of potential preemption. The remainder of this article attempts to find patterns in those cases.

62 See generally, Jason A. Kidd, Casenote: The Ninth Circuit Falls Short While Establishing the Proper Perfection Method for Security Interests in Patents in In Re Cybernetic Services, 36 CREIGHTON L. REV. 669 (2003) (comparing the Ship Mortgage Act of 1920, the Federal Aviation Act of 1958 and the Copyright Act with the Patent Act). 


\section{Federal Interests Do Not Require Preemption of Article 9's Rules Governing the Relationship Among Secured Creditors, Bankruptcy Trustees, and Lien Creditors.}

As posited above, case law indicates that a creditor can perfect its security interests in patents under Article 9 and enjoy priority over bankruptcy trustees and other lien creditors of the debtor in accordance with Article 9's priority scheme. ${ }^{63}$ Recently, in Cybernetic Services,${ }^{64}$ the Ninth Circuit considered the argument of a bankruptcy trustee who, as a hypothetical lien creditor, claimed that his interest in patents had priority over the security interest of a secured creditor claiming to have perfected its security interest by filing a financing statement covering "general intangibles" pursuant to the California Uniform Commercial Code as then in effect. ${ }^{65}$ The bankruptcy trustee argued that failure of the secured creditor to record its interest with the Patent and Trademark Office ("PTO") in accordance with the requirements of the Patent Act left its security interest unperfected.

The trustee's argument was based on section 261 of the Patent Act which provides that applications for patents, patents themselves and interests in patents may be assigned "by an instrument in writing." But, such an assignment is "void as against any

63 See, e.g., City Bank \& Trust Co. v. Otto Fabric, Inc., 83 B.R. 780 (D.Kan. 1988); In re Transp. Design and Tech., Inc., 48 B.R. 635 (Bankr. S.D. Cal. 1985); Chesapeake Fiber Packaging Corp. v. Sebro Packaging Corp., 143 B.R. 360 (D.Md.), aff'd 8 F.3d 817 (4th Cir. 1993); Holt v. United States, 73-2 T.C. 9680 (1973).

${ }^{64}$ In re: Cybernetic Servs., 252 F.3d 1039 (9th Cir. 2001). See also, In re: Pasteurized Eggs Corp., 296 B.R. 283 (Bankr. N.H. 2003).

65 In 2001, all states adopted substantial revisions to Article 9. References in this article to Article 9 are to the revised uniform version of Article 9, but the basic framework, of the old version of Article 9 addressed by the Cybernetic Services court remained the same. Under both versions of Article 9, a secured creditor can perfect a security interest in a general intangible by filing a financing statement in the appropriate state location. The bankruptcy trustee argument argued that a state law permitting perfection of a security interest pursuant to state law was preempted by federal recording requirements. 
subsequent purchaser or mortgagee for a valuable consideration, without notice, unless it is recorded in the [PTO] within three months from its date or prior to the date of such subsequent purchase or mortgage." The trustee acknowledged that the Patent Act does not contain terms expressly preempting state secured transactions laws, but argued that preemption principles should be applied to displace the UCC filing requirements with the federal recording system and thereby to maintain the integrity of the federal recording patent system. ${ }^{66}$

The Ninth Circuit abruptly dismissed the trustee's argument that all matters governing security interests were preempted by federal law, because it was clear that the Patent Act does not require a creditor to record its interest with the Patent and Trademark Office in order to perfect its security interest as to subsequent lien creditors, such as the bankruptcy trustee. ${ }^{67}$ The relationship between creditors of a patent owner was outside of the federal interest relating to innovation and free exchange of information. The Court then turned to the bankruptcy trustee's argument that section 261 of the Patent Act preempts Article 9 by displacing all state law relating to records of ownership interests in patents. Assignments are "void" as against subsequent purchasers and mortgagees on patents unless recorded in the federal records in accordance with section $261{ }^{68}$ Interpreting section 261, the Court reviewed the meaning given to the terms "assignment" and "mortgagee" in 1870 when they were incorporated into federal law. At that time,

\footnotetext{
${ }^{66}$ In re Cybernetic Servs., 252 F.3d at 1047.

${ }^{67} I d$. at $1057-58$.

${ }^{68} \mathrm{Id}$.
} 
collateral was obtained by security devices such as pledges, ${ }^{69}$ mortgages, ${ }^{70}$ and assignments, ${ }^{71}$ not by security interests. Unlike security interests, ${ }^{72}$ the older type of security devices actually conveyed an ownership interest to the lienor. This is why, in Waterman v. Mackenzie, ${ }^{73}$ the Supreme Court said that a mortgagee had the right to sue on a patent even though those rights were reserved to parties with title to the patent, and not mere licensees. ${ }^{74}$

In fact, the idea that collateral devices such as conditional "assignments" can

69 "Pledge" is defined as "a. the act of delivering goods, property, etc, to another for security. b. the resulting legal relationship. 5. something given or regarded as a security.", at http://www.factmonster.com/ipd/A0592283.html, (last visited February 23, 2005) (On file with Pittsburgh Journal of Technology, Law and Policy).

70

"Mortgage" is defined as:

The transfer of title to real estate which is made to secure the performance of some act such as payment of money by the person making the transfer. Upon the performance of the act, the grantee agrees to convey the property back to the person who has conveyed it to him.

Mortgages are of several kinds: as they concern the kind of property, mortgages, they are mortgages of lands, tenements, and, hereditaments, or of goods and chattels; as they affect the title of the thing mortgaged, they are legal and equitable. In equity all kinds of property; real or personal, which are capable of an absolute sale, may be the subject of a mortgage; rights in remainder and reversion, franchises, and choses in action, may, therefore, be mortgaged; But a mere possibility or expectancy, as that of an heir, cannot. A legal mortgage of lands may be described to be a conveyance of lands, by a debtor to his creditor, as a pledge and security for the repayment of a sum of money borrowed, or performance of a covenant with a proviso, that such conveyance shall be void on payment of the money and interest on a certain day, or the performance of such covenant by the time appointed, by which the conveyance of the land becomes absolute at law, yet the, mortgagor has an equity of redemption, that is, a right in equity on the performance of the agreement within a reasonable time, to call for a reconveyance of the land. at http://www.lectlaw.come/def2/m040.htm, (last visited February 23, 2005) (On file with Pittsburgh Journal of Technology, Law and Policy).

71 “Assignment" has been defined as the "act of transferring rights or power." http://www.legaldefinitions.com/assignment.htm

72 Section 9-202 of the UCC says: "Except as otherwise provided with respect to consignments or sales of accounts, chattel paper, payment intangibles, or promissory notes, the provisions of this article with regard to rights and obligations apply whether title to collateral is in the secured party or the debtor."

73

138 U.S. $252(1891)$.

74

Id. at $255,258,260-261$. 
convey title to patents to creditors is still relevant today. Specifically addressing the effect of assignments recorded with the PTO pursuant to the recording provisions of section 261 of the Patent Act, 37 C.F.R. 3.1 says that "assignment" is "a transfer by a party of all or part of its right, title and interest in a patent or patent applications...." According to the Manual of Patent Examining Procedure, an assignment transfers to another party a "bundle of rights that is associated with the ownership interest, i.e., all of the bundle of rights that are inherent in the right, title and interest in the patent or patent application., ${ }^{, 75}$ The Manual of Patent Examining Procedure distinguishes "security interests" of the type created under Article 9 from other types of legal interests that transfer of title or ownership rights ${ }^{76}$ noting that: "A security agreement that does not convey the right, title, and interest of a patent property is not a conditional assignment." ${ }^{, 77}$ Consistent with the wording in Waterman, the Cybernetic Services court stated that anything that does not convey an ownership interest in a patent is a "mere license."78 While a holder of a "mortgage" (as that term is used in section 261 of the Patent Act), such as the mortgagee in the Waterman case, has standing to sue on a patent, under modern law, secured parties no more expect to have rights in their collateral entitling (or obligating) them to maintain actions in respect of their collateral than do licensees. The Cybernetic Services court concluded that the types of security devices governed by the recording requirements of

\footnotetext{
75 Manual of Patent EXamining Procedure $\S 300-2$ (August 2001).

76 Id. at 300-13. See also 37 C.F.R. § 3.56 (2005).

77 ManUAl of PATENT EXAMINING PROCEDURE at 317.03; See generally Haemmerli, supra note 39.

78 See In re: Cybernetic Servs., 252 F.3d at 1052.
} 
section 261 are devices, such as mortgages, that involve transfer of title to a patent. ${ }^{79}$

Everything else is a license ${ }^{80}$ that does not have to be recorded in order to be effective. ${ }^{81}$

As a result, the state law governing security interests is not preempted by the Patent Act's

recording requirements, and security interests perfected by filing financing statements

can be accorded the priority over bankruptcy trustees accorded to other security interests

similarly perfected. Section 261 of the Patent Act does not require something to be

recorded with the PTO in order for that security interest to achieve protections otherwise

given to it by state law.

In permitting a secured creditor who files a financing statement to prevail over a

bankruptcy trustee (and, in so doing, holding that section 261 of the Patent Act does not

preempt Article 9 for this purpose), the Cybernetic Services holding was consistent with

${ }^{79}$ Id. at $1052-53$.

80 "A license... is a contract whereby the owner of the patent (the patentee or an assignee) allows the licensee to make, use or sell the invention." Donald Shelby Chisum, The Allocation of Jurisdiction Between State and Federal Courts in Patent Litigation, 46 WASH. L. REV. 633, 645 (1971).

81 The Lanham Act, which governs trademarks, has a provision similar to Section 261 of the Patent Act. 15 U.S.C. § 1060(a)(4) (2004) says that "An assignment shall be void against any subsequent purchaser for valuable consideration without notice, unless the prescribed information reporting the assignment is recorded in the United States Patent and Trademark Office within three months after the date thereof or prior to the subsequent purchase." Consistent with Cybernetic Services, it has generally been held that security interests perfected by filing financing statements will have priority over the interests of bankruptcy trustees. See In re TR-3 Industries, 41 B.R. 128 (Bankr. C.D. Cal. 1984) (purpose of the act is not to govern perfection of security interests); In re Roman Cleanser, 802 F.2d 207 (6 $6^{\text {th }}$ Cir. 1986); In re Chattanooga Choo-Choo Co., 98 B.R. 792 (Bankr. E.D. Tenn. 1989) (UCC governs perfection of security interest in service marks); In re 199Z, Inc., 137 B.R. 778 (Bankr. C.D. Cal. 1992) (Lanham Act covers assignments, not mortgages, pledges or hypothecations); Trimarchi v. Together Development Corp., 255 B.R. 606 (D. Mass. 2000) (Lanham Act filing system did not preempt the UCC for purposes of perfecting a security interest). On the other hand, the recording provisions of the Copyright Act (15 U.S.C. 205) ("Any transfer of copyright ownership or other document pertaining to a copyright may be recorded in the Copyright Office... As between two conflicting transfers, the one executed first prevails if it is recorded... within one month after its execution in the United States or within two months after its execution outside the United States, or at any time before recordation in such manner of the later transfer. Otherwise the later transfer prevails...") have been held to require the recordation of security interests in order to prevail as against subsequent bankruptcy trustees. In re Peregrine Entertainment, Ltd., 116 B.R. 194 (C.D. Cal. 1990) (Copyright Act provides a national system for recording security interests in copyrights); In re World Auxiliary Power Co., 303 F.3d 1120 ( $9^{\text {th }}$ Cir. 2002) (federal recording system does not require recording as to unregistered copyrights). 
and expanded on the logic of the holding in In re Transportation Design and Technology, Inc. ${ }^{82}$ However, rather than turning on section 261's preemption of Article 9 filing requirements, this case looked at whether a bankruptcy trustee could assume the position of a hypothetical assignee of a patent who would have priority over an interest not recorded pursuant to section 261. Since a bankruptcy trustee is a hypothetical lien creditor under the Bankruptcy Code, but not a purchaser for value of personal property entitled to priority under the Patent Act, the secured party had priority over the interests of a bankruptcy trustee. The Cybernetic Services holding was also consistent with the holding in City Bank and Trust Co. v. Otto Fabric, Inc. ${ }^{83}$ in which the Court found persuasive the argument that amendments to the Patent Act made since the development of secured transactions law under the UCC had not addressed security interests.

In sum, a bankruptcy trustee's interest in patents does not prevail over a perfected security interest, because state law addressing the conflict between these two parties does not touch on areas of federal interest. Case law supports several logical conclusions based on the rationale of these cases. First, as expected when hypothetical lien creditors cannot find support in federal law to prevail over creditors holding security interests perfected under Article 9, the Court in Charles C. Holt v. United States ${ }^{84}$ looked to state law to determine the relationship between a secured creditor and an actual tax lienor. Second, since federal law does not preempt state laws allocating priorities between security interests and lien creditors, that law should not tamper with relationships

8248 B.R. 635 (Bankr. S.D. Cal. 1985).

8383 B.R. 780 (D. Kan. 1988).

${ }^{84}$ Charles C. Holt v. United States, 73-2 U.S. Tax Cas. (CCH) 9680 (D.D.C. 1973). 
between other state lienors generally. In fact, the relationship between a security interest and an attorney's lien was determined under state law in the case of Hedman, Gibson \& Costigan, P.C. v. Tri-Techsystems International, Inc. ${ }^{85}$

\section{Federal interests do not require preemption of Article 9's rules governing the relationship between secured parties and debtors.}

Cases holding that Article 9 governs the relationship between secured parties and others claiming a lien on patents pursuant to state law are consistent with the conclusion that, to the extent the relationship between secured parties and debtors are governed by state law, Article 9 dictates the nature of the relationship. By engaging in the consensual act of creating and perfecting a security interest, the owner of a patent is granting a secured party the right to divest the owner of the patent interest upon a default in a transaction. There is no explicit conflict between the Patent Act and a state legal system that permits owners to transfer patents and patent applications contingently.

Under the Patent Act, patent applications are made in the name of the inventor and, absent a transfer of ownership rights by the inventor, are issued in his name. ${ }^{86}$ However, the Patent Act does not tell patent owners the contractual formulation to be used in effectuating transfers. A contingent transfer such as a grant of a security interest in a patent would not have any effect that would be contrary to the federal goal of keeping information in the public domain. Nor would such a contingent transfer, in itself, have an effect contrary to the federal goal of encouraging innovation through

\footnotetext{
85 Hedman, Gibson \& Costigan, P.C. v. Tri-Tech Systems Int'1, Inc., 92 Civ. 2757, 1995 U.S. Dist. LEXIS 13538 (S.D.N.Y. Sept. 18, 1995).

${ }^{86}$ Chisum, supra note 78 at 645-46.
} 
providing protection from infringement of patents.

Of course, it is possible to imagine transactions in which an abusive secured party uses a secured transaction essentially to "steal" the collateral and, in so doing, potentially take an action at odds with the goal of federal patent laws. For example, a secured party could extend credit secured by patents knowing that the debtor will default and that the secured creditor will be able to sell the patent collateral to a competitor of the original patent owner, but there are safeguards in both Article 9 and in other state laws governing commercial transactions designed to protect debtors from such abusive practices.

Under Article 9, "[e]very aspect of a disposition of collateral, including the method, manner, time, place, and other terms, must be commercially reasonable. ${ }^{187}$ If the proceeds of collateral exceed the cost of disposition and the amounts secured by the collateral, the secured party must account to the debtor for the surplus. ${ }^{88}$ The secured party itself may not purchase collateral through a private disposition unless the collateral "is customarily sold on a recognized market or the subject of widely distributed standard price quotations. ${ }^{\prime 89}$ Moreover, if the disposition of collateral is made to the secured party, a party related to the secured party, or a secondary obligor ${ }^{90}$ and the amount received upon disposition was "significantly below the range of proceeds" that would otherwise have been received, the amount of any surplus payable to a debtor is calculated
87 U.C.C. $\S 9-610(b)(1999)$.
$88 I d . \S 9-608(\mathrm{a})(4)$.
${ }^{89}$ Id. § 9-610(c).
90 Under U.C.C. § 9-102(a)(71), a "secondary obligor" is "an obligor to the extent that: (A) the obligor's obligation is secondary; or (B) the obligor has a right of recourse with respect to an obligation secured by collateral against the debtor, another obligor, or property of either." 
based, not on actual proceeds received or credited from a disposition, but rather on the amount that would have been received in a disposition complying with Article $9 .{ }^{91}$

While there is a dearth of definitive precedent directly addressing whether an Article 9 security interest in a patent is, in all respects, enforceable against a debtor in accordance with applicable state law, the cases discussed above addressing the relationship between secured parties and other state law interests necessarily assume that those state law-based interests are enforceable against the underlying debtor. If they were not, the holdings in the cases would have constituted unfounded discussion about conflicting claims to unenforceable rights. Whether federal patent interests would offer refinements to the relative rights of patent owners and secured parties in the right cases, nevertheless, remains uncertain.

\section{The Patent Act necessarily preempts some of Article 9's rules governing interests of subsequent transferees of patents.}

Consistent with the conclusion that, as between a debtor and a secured party, federal law generally need not preempt state law, in practice, state law is generally applied to address questions about voluntary transfers of patents ${ }^{92}$ and patent licenses. ${ }^{93}$ However, federal interests are sometimes brought to bear to preempt state law dealing with transfers of interests in patents. For example, federal patent law, rather than state

\footnotetext{
91 Id. $\S 9-615(\mathrm{f})$.

92 Jim Arnold Corp. v. Hydrotech Systems, Inc., 109 F.3d 1567 (Fed. Cir. 1997), cert. den sub nom. Baker Hughes Inc. v. Jim Arnold Corp. 522 U.S. 933 (1997); Lerco Corp. v. Ernest K. Haley and Haley's Drills, Inc. , 597 F. Supp. 517 (W.D. Ken. 1983).

93 Farmland Irrigation Co. v. Dopplmaier, 308 P.2d 732 (1957). But see Unarco Indus. Inc. v. Kelley Co., 465 F.2d 1303 (7th Cir. 1972) (finding, contrary to the Farmland case, that the federal policies reflected in the Patent Act are so intertwined with licensing that federal, not state law, should govern).
} 
law, has been applied to permit (i) transfers of nonexclusive licenses (or "shop rights") to employers of inventors, ${ }^{94}$ (ii) patent applications to be filed by an employer of an inventor, ${ }^{95}$ (iii) the transfer of "shop rights" in connection with the transfer of the whole business, ${ }^{96}$ (iv) transfer of licenses to pass from a corporation to another company formed by a merger, ${ }^{97}(\mathrm{v})$ transfer of a license from a partnership into a corporation to which the partnership transferred its assets, ${ }^{98}$ and (vi) transfer of a license from one licensee to another party if the licensor agrees. ${ }^{99}$ Federal patent law, not state law, has also been the basis of cases inhibiting (i) transfers of licenses by debtors in bankruptcy, ${ }^{100}$ (ii) assumptions of licenses by debtors in possession, ${ }^{101}$ (iii) transfers of licensees' rights to their estate ${ }^{102}$, (iv) transfers of implied licenses, ${ }^{103}$ and (v) transfers of licenses that may,

94 See, e.g., Mechmetals Corp. v. Telex Computer Prod., Inc., 709 F.2d 1287 (9th Cir. 1983); Wommack v. Durham Pecan Co., 715 F.2d 962 (5th Cir. 1983).

95 See, e.g., Bausch \& Lomb, Inc v. Barnes-Hind/Hydrocurve, Inc., 796 F.2d 443 (N.D. Cal. 1989).

96 Lane \& Bodley Co. v. Locke, 150 U.S. 193 (1893).

97 Lightner v. Boston \& Albany R.R., 15 F. Cas. 514 (D. Mass. 1869) (No. 8343).

98 Locke, 150 U.S. at 196 (in this case the owner of the patent permitted the corporation to continue using the patent for a period of time).

99 Bowers v. Lake Superior Contracting \& Dredging Co., 149 F. 983, 988 (8th Cir. 1906) (the executrix of licensee who was treated by the licensor as entitle to use the licensed rights and could transfer the licensee's business including rights under licenses).

100 See Unarco Indus., Inc. v. Kelley Co., 465 F.2d 1303 (7th Cir. 1972); PPG Indus., Inc. v. Guardian Indus. Corp., 597 F.2d 1090 (6th Cir. 1979); Everex Sys., Inc. v. Cadtrak Corp. (In re CFLC, Inc.), 89 F.3d 673, (9th Cir. 1996); Stephen Perlman v. Catapult Entm't, Inc. (In re Catapult Entm't), 165 F.3d 747 (9th Cir. 1999); In re Alltech Plastics, Inc., 71 B.R. 686 (Bankr. W.D. Tenn. 1987).

101 Perlman, 165 F. 3d 747, 754-55 (1999). But see Institut Pasteur v. Cambridge Biotech Corp., 104 F.3d 489, 493-94 (1st Cir. 1997) (permitting assumption of a license where there would be no assignment in violation of the license terms).

102 Oliver v. Rumford Chem. Works, 109 U.S. 75 (1883).

103 Hapgood v. Hewitt, 119 U.S. 226 (1886). 
on their face, permit transfer. ${ }^{104}$

The fact that federal law may affect transfers of interests in patents in these cases would not necessarily surprise secured parties who have bargained for interests in patents knowing that those interests are the product of federal law, nor is the fact that federal law may affect transfers of patents necessarily inconsistent with applicable state law.

However, what may be surprising to secured parties and appear to be inconsistent with applicable state law can be found in those ill-defined areas where the scope of federal preemption has yet to be determined. ${ }^{105}$ It is in these areas of potential preemption, ${ }^{106}$ such as those dealing with ownership and transfer issues, ${ }^{107}$ that the inexact contours of security interests in patents are highlighted.

Article 9 ventures into these vulnerable areas most starkly when it deals with the relationships between secured parties and transferees of collateral. Generally speaking, unless a secured party otherwise agrees, its security interest in collateral continues to be effective as against subsequent owners ${ }^{108}$ and their secured creditors. ${ }^{109}$ If collateral is

104 Troy Iron \& Nail Factory v. Corning, 55 U.S. 193 (1853).

105 See generally Raymond T. Nimmer, Breaking Barriers: The Relation Between Contract and Intellectual Property Law, 13 BERKELEY TECH. L.J. 827 (1998) (examining the interaction between contract and intellectual property law); David R. Kuney, Intellectual Property Law in Bankruptcy Court: The Search for a More Coherent Standard in Dealing with a Debtor's Right to Assume and Assign Technology Licenses, 9 AM. BANKR. INST. L. REV. 593 (2001) (discussing issues arising from the intersection of intellectual property and bankruptcy law).

106 See Nimmer, supra note 103, at 860.

107 Mark A. Lemley, The Law and Policy of Intellectual Property Licensing," 87 CAL. L. REV. 111, 116 (1999).

108 Under U.C.C. § 9-315, “a security interest or agricultural lien continues in collateral notwithstanding sale, lease, license, exchange or other disposition thereof unless the secured party authorized the disposition free of the security interest or agricultural lien...."

109 U.C.C. § 9-325(a) generally provides that "a security interest created by a debtor is subordinate to a security interest in the same collateral created by another person if... (1) the debtor acquired the collateral 
transferred to a debtor in another jurisdiction, the security interest can remain perfected for up to a year without filing a financing statement against the new owner. ${ }^{110}$ If collateral is transferred to a person located in the same jurisdiction as the transferor, the security interest can remain perfected throughout the original financing statement's effective period without filing a new financing statement even if the name of the new owner is entirely different from that of the original debtor. ${ }^{111}$ To achieve commercially expected ends, under sections 9-320(a) ${ }^{112}, 9-321(\mathrm{c})^{113}$ and 9-321(b) ${ }^{114}$ of Article 9, a secured party's security interest can cease to be effective as against a subsequent "buyer in ordinary course of business,"115 "licensee in ordinary course of business, ${ }^{116}$ or "lessee

subject to the security interest created by the other person; (2) the security interest created by the other person was perfected when the debtor acquired the collateral; and (3) there is no period thereafter when the security interest is unperfected."

${ }^{110}$ U.C.C. $\$ 9-316(a)(3)$ says that a security interest that is property perfected under the law of another jurisdiction remains perfected until "the expiration of one year after a transfer of collateral to a person that thereby becomes a debtor and is located in another jurisdiction."

111 See generally, Edwin Smith, The Resolution of "Double Debtor" Issues Under Revised UCC Article 9, Commercial Law Newsletter, October 8, 2001, available at http://www.acfa.cc/meeting_materials/011016/double_debtors.pdf (on file with the Pittsburgh Journal of Technology Law and Policy).

112 U.C.C. $\S 9-320$ (a) states that "a buyer in ordinary course of business...takes free of a security interest created by the buyer's seller" even if the security interest predated the sale.

113 U.C.C. $\S 9-321$ (c) states, "[a] lessee in ordinary course of business takes its leasehold free of a security interest in the goods created by the lessor, even if the security interest is perfected and the lessee knows of its existence."

114 U.C.C. $\S 9-321$ (b) states, “[a] licensee in ordinary course of business takes its rights under a nonexclusive license free of a security interest in the general intangible created by the licensor, even if the security interest is perfected and the licensee knows of its existence."

115 U.C.C. $\S 1-201(b)(9)$ of the UCC defines "buyer in ordinary course of business" in part as "a person that buys goods in good faith, without knowledge that the sale violates the rights of another person in the goods, and in the ordinary course of business of selling good of that kind. A person buys goods in the ordinary course if the sale to the person comports with the usual or customary practices in the kind of business in which the seller is engaged or with the seller's own usual or customary practices." 
in ordinary course of business. ${ }^{, 117}$ To facilitate the transfer of collateral when a secured party forecloses on assets that are subject to an official recording system, section 9619(b) specifically permits a secured party to transfer of record all rights of debtor "in any official ...recording...system," but as observed by Official Comment 1 to that section, "use of this mechanism will not be effective to clear title to the extent that subsection (b) is preempted by federal law."

As a practical matter, these provisions of Article 9 mean that transferees of most personal property who do not fall into protected categories of subsequent owners must conduct a search of the financing statement records maintained in the state where the prior owner is located ${ }^{118}$ in order to ascertain the existence of security interests perfected by filing in that state. In addition, during the transition phase from the old filing rules to the new ones that became effective in 2001, transferees may need to consult the records of states where financing statements had to be filed prior to the enactment of the new version of Article 9. ${ }^{119}$

Some of these provisions of Article 9 necessarily run contrary to the Patent Act

116 U.C.C. § 2A-103(1) (o) of the UCC defines "lessee in the ordinary course of business" in part as "a person who, in good faith and without knowledge that the lease to him or her is in violation of the ownership rights or security interest or leasehold interest of a third party in the goods, leases in the ordinary course of business of selling or leasing goods of that kind, but does not include a pawnbroker."

${ }^{117}$ U.C.C. § 9-321(a) defines "licensee in ordinary course of business" as a person that becomes a licensee of a general intangible in good faith, without knowledge that the license violates the rights of another person in the general intangible, and in the ordinary course of business from a person in the business of licensing general intangibles of that kind. A person becomes a licensee in ordinary course if the license to the person comports with the usual or customary practices in the kind of business in which the licensor is engaged or with the licensor's own usual or customary practices."

118 See supra note 34 and accompanying text.

119 See generally, Harry C. Sigman \& Edwin E. Smith, Revised U.C.C. Article 9's Transition Rules: Insuring a Soft Landing - Part 1, 55 Bus. LAW. 1065 (2000); Harry C. Sigman \& Edwin E. Smith, Revised U.C.C. Article 9's Transition rules: Insuring a Soft Landing-Part 2, 55 Bus. LaW. 1763 (2000). 
and are surely preempted. Section 261 of the Patent Act explicitly provides that purchasers or mortgagees for value and without notice of a prior transfer have priority over the prior transfer. As a result, a transferee acquiring a patent upon disposition by a secured party whose security interest was perfected under state law by filing a financing statement would appear to take that patent interest subject to the interest of any prior purchaser or mortgagee (even if the purchase or mortgage was consummated after the security interest was created), unless the prior purchaser mortgagee was tainted with knowledge or did not take for value. ${ }^{120}$ This conclusion is consistent with cases holding that perfected security interests have priority over the interests of bankruptcy trustees, because, as noted in Cybernetic Services, a secured party is a "mere licensee," and according to the Waterman case, a "mere licensee" is not entitled to protection from subsequent transferees.

In fact, the decision in In Chesapeake Fiber Packaging Corp. v. Sebro Packaging Corp. ${ }^{121}$ assumed that subsequent transferees would have priority over prior perfected security interests. In Chesapeake, a party sought to establish that by prosecuting a patent, a subsequent purchaser would obtain priority over a security interest perfected by filing a financing statement. While the Court rejected the argument that the party was a subsequent purchaser for purposes of section 261 , it did not reject the idea that a subsequent purchaser could have priority over a security interest perfected under state law. Other commentators have also concluded that perfected security interests have no

${ }^{120}$ But see, Jeffrey S. Turner, Security Interests in Patents After Cybernetic Services, State BAR OF CALIFORNIA BUSINESS LAW NEWS, Summer 2001, at 1,12, 13, (arguing that treating a security agreement as a license means that subsequent mortgagees and assignees take subject to the security agreement just as they would take subject to licenses).

121143 B.R. 360 (D. Md. 1992), aff'd, 8 F. 3d 817 (4th Cir. 1993). 
effect on subsequent transferees and, perhaps more startling to secured creditors, their security interests may be subordinate to subsequent mortgagees who benefit from the title transfer quality of the older forms of collateral devices. ${ }^{122}$

While Cybernetic Services did not have to discuss the effect of a perfected security interest on subsequent transferees in order to address the bankruptcy trustee's argument that the federal recording system is intended to function as the only public source of information about interests in patents, the Cybernetic Services decision is consistent with a line of cases relegating security interests to something less than the type of ownership interest that the federal recording system was created to protect. ${ }^{123}$ In reaching its conclusion, the Court relied on an old Supreme Court case, Littlefield $v$. Perry ("Littlefield"), ${ }^{124}$ in which there was a dispute between the assignee of a recorded grant and the assignor who held an unrecorded agreement contractually entitling the grantor to certain rights. The Littlefield court stated that "[t]he record is intended for the benefit of the public. The record of the grant alone, therefore, furnishes the strongest evidence of the intention of the parties to give effect to the... instruments as an

\footnotetext{
122 "Dictum in [the In re Transportation Design \& Technology, Inc.] case, focusing on Patent Act preemption of state UCC law with regard to title transfers, leaves creditors suspended over a gulf between federal and state law: they cannot perfect a security interest as against a subsequent purchaser under the UCC because anything involving title to patents is regulated by the Patent Act." Haemmerli, supra note 39 at 1655 . "A subsequent purchaser or mortgagee for value and without notice would trump an unrecorded assignee, including a secured creditor who has taken a collateral assignment but failed to record it, irrespective of that later purchaser's or mortgagee's recordation. The prior assignment would simply be void as against the subsequent assignee. This is typical of a notice, as opposed to a race-notice, statute: 'a purchaser takes priority over all prior unrecorded interests of which he had no notice when he took." Id. at 1701 n.282.
} 
assignment.",125

Article 9 cannot give to a secured party whose security interest is perfected by filing a financing statement the right to foreclose on patents after they have been transferred to a purchaser or mortgagee for value and without notice, because to do so would upset the intended effect of federal recording envisioned by the Littlefield court. The federal patent records would not have the persuasive evidentiary effect that they necessarily must have to serve their intended function, and those interested in ascertaining potential ownership interests in patents would have to conduct the same types of searches of state records as are expected of creditors secured by most types of other personal property. They would have to search both state and federal records to ascertain security interests granted by current and prior owners. Only then could ownership (and the right to transfer) be adequately established.

\section{Preventing subsequent transferees from taking patents free of security interests.}

Since the Patent Act does not protect ownership rights in a patent acquired by subsequent transferees "with notice," a question arises as to when subsequent transferees have sufficient notice so as to protect secured parties relying on their rights under state law. Even though the federal record necessarily has a sacrosanct role in reflecting patent ownership, it can be argued that filing a financing statement could put subsequent transferees on sufficient notice so as to protect the rights accorded to a secured party by state law, and such an argument would not necessarily produce a result that is

125 Id. at 221. 
inconsistent with federal law.

As used in section 261, "notice" includes actual, constructive and inquiry notice. ${ }^{126}$ This potentially means that prudent transferees of patents operating in a modern world will search for financing statements encumbering the patents and thereby be put on notice of conflicting interests that will prevent them from taking free of existing security interests. Case law supports this line of thought somewhat. In $\mathrm{Katz}^{127}$, a transferee searched the PTO records and found no record of a prior transfer that had actually occurred but not recorded. The transferee argued that searching the records was all that was required " in his exercise of ordinary care under the circumstances" and that, absent an indication of a prior transfer in those records, he was under no obligation to make further inquiry. ${ }^{128}$ The Court disagreed:

We believe, as did the district court, that a person in Katz's circumstances exercising ordinary care should have asked these minimal, obvious questions. Willful or careless blindness is not the sort of lack of notice that section 261 contemplates. The evidence of record therefore contains no factual dispute to preclude a determination as a matter of law that Katz should be held to constructive notice, based on a duty of inquiry, of the prior assignment. ${ }^{129}$

Of course, in the absence of case law on the matter, secured parties would be reluctant to place much reliance on the argument that a transferee is "on notice" of a conflicting interest evidenced by a financing statement filed in state records. However, to

126 See W. Simon Katz v. Lear Siegler, Inc. et al, No. 91-1094, 1993 U.S. App. LEXIS 17505 (Fed. Cir. Jul. 12, 1993).

127 Id.

${ }^{128}$ Id. at $* 12$.

129 Id. at $* 15$. 
the extent that transferees of patents and patent applications are acquiring other personal property (such as good will or other general intangibles) in connection with the acquisition of the patents and patent applications and, as a matter of good business practice, search the financing statement records to ascertain potentially conflicting security interests in that personal property, they would have actual notice of any perfected security interests in patents. ${ }^{130}$

To add evidentiary weight to the argument that subsequent transferees necessarily are "on notice" of existing security interests, secured parties commonly file notices of their interests with the PTO in accordance with federal regulations that specifically permit the recordation of assignments of applications, patents, registrations and other "documents" $" 131$ so long as they are accompanied by an appropriate cover sheet. The Manual of Patent Examining explains that the PTO permits the recording of security agreements "in the public interest in order to give third parties notification of equitable interests or other matters relevant to the ownership of a patent or application." "132 To record a security agreement, a secured party sends to the PTO a "document" accompanied by a cover sheet on which it has checked the box "security agreement" to describe the "nature of conveyance." The debtor's name appears on the cover sheet as the "Conveying Party" while the secured party's name is reflected as the "Receiving

130 See generally Haemmerli, supra note 39 at 1707.

13137 C.F.R. $\S 3.11$ (2004). A "document" is a "document which a party requests to be recorded in the [PTO] pursuant to [Section 3.11 of the Code of Federal Regulations] and which affects some interest in an application, patent, or registration." Id. §3.1.

132 Manual of Patent Examining Procedure 300-13 (8th ed. 2001). 
Party." ${ }^{\prime 133}$ To facilitate identifying security agreements with specific patents and patent applications, the cover sheet requires the recording party to identify patents and patent applications by numbers (including the series code and six-digit number with such additional identifying information as is applicable to international applications). Notwithstanding the terminology of the cover sheet treating a security agreement as a conveyance, the Patent Examining Manual states that "[a] security agreement that does not convey the right, title and interest of a patent property is not a conditional assignment. ${ }^{134}$

Although it has become common practice for notice of security interests in patents and patent applications to be recorded in the federal patent records, ${ }^{135}$ secured parties are left to ponder whether anything that they have recorded will have the effect of putting subsequent purchasers and mortgagees on sufficient notice to prevent them from taking free of a pre-existing security interest. There is no federal law stating that recording a security agreement or notice of security interest puts subsequent purchasers or mortgagees on notice of any potential subsequent effect of a security interest, and the PTO takes no position on the effect of recordation. In fact, the Code of Federal Regulations says that the recording of documents by the PTO does not constitute an acknowledgement that the documents have any effect. ${ }^{136}$ Without constructive notice being imputed to purchasers and mortgagees, actual notice or receipt of inquiry notice

13337 C.F.R. $\$ 3.31$ (2004); Manual of Patent Examining Procedure at 300-6 (Form PTO-1595).

134 Manual of Patent EXAmining Procedure $\$ 317.03$ (8th ed. 2001).

${ }^{135} I d$.

${ }^{136} 37$ C.F.R. $\$ 3.54$ (2004). 
would have to be proven in the event of a dispute between a secured creditor and a subsequent purchaser or mortgagee for value. ${ }^{137}$

If a subsequent purchaser or mortgagee searches the patent records and finds evidence of a security interest, an argument can be made that the subsequent party then has notice of a prior security interest and would take subject to the rights of a secured creditor, including the right to sell the patent and to divest the subsequent transferee of its interest. In the absence of a clear body of law addressing the circumstances in which a secured party would prevail over subsequent transferees and mortgagees under these circumstances, there are inherent limitations in the value attributable by secured parties to patents in which security interests are perfected by filing a financing statement, even when the secured party also recorded evidence of its security interest with the PTO.

The potentially limited value of filing security documents with the PTO is further undermined by the very nature of the process. A "floating lien" created under Article 9 covering after-acquired collateral cannot effectively be memorialized in a federal filing that is tied to specific patent and application numbers by the cover sheet under which the filing is made. By making such a filing with the PTO, a secured party could be said to have made a public record that is inconsistent with the rights that the secured party argues that it has under Article 9. To the extent that the federally recorded interest of a secured party is limited to those items specifically identified in the related cover sheet, the secured party may have done the best that he can to protect his rights, but he has virtually relinquished any federal protection for his security interest in after-acquired patents and patent applications as well as proceeds of patent collateral, including interest in substitute

137 See Haemmerli, supra note 39. 
or continuation-in-part applications filed with respect to the subject matter of the initial application, perfected under Article $9 .^{138}$

\section{The value of security devices other than security interests under Article 9.}

To avoid diluting the value attributable to patents, a secured party could revert to older forms of collateral devices. Section 261 of the Patent Act on its face addresses "mortgages" and "assignments." Mortgages and conditional assignments are forms of collateral devices that evolved prior to Article 9. ${ }^{139}$ Although federal regulations do not specifically address mortgages, they do specify the rights accorded to holders of conditional assignments. According to 35 C.F.R. Section 3.56:

[A]ssignments which are made conditional on the performance of certain acts or events, such as the payment of money or other condition subsequent, if recorded in the Office, are regarded as absolute assignments for Office purposes until canceled with the written consent of all parties or by the decree of a court of competent jurisdiction. The Office does not determine whether such conditions have been met.

A security agreement is distinguished from a conditional assignment for this purpose by the Manual of Patent Examining Procedure: Since mortgages, like conditional assignments, generally have been viewed as documents conveying ownership rights to the mortgagees, ${ }^{140}$ many of the rules applicable to conditional assignments seem also to

\footnotetext{
138 MANUAl of PATENT EXAmining Procedure 300-11 (8th ed. 2001) (stating while federal regulations do not address the effect of recorded security agreements or whether original patent or application descriptions would require correction in these events, logic behind the regulations dealing with conditional assignments would suggest that there are events in which a recorded security interest would have to be amended if there were a substitute or continuation-in-part application filed).

139 See Haemmerli, supra note 39.

140 See Haemmerli, supra note 39; Waterman, 138 U.S. at 258-60.
} 
be applicable to mortgages.

Assignment documents are recorded by the Assignment Division of the PTO, ${ }^{141}$ and once recorded, those records generally ${ }^{142}$ are searchable by the public ${ }^{143}$ (separately from applications). ${ }^{144}$ Since, as in the case of the cover sheets accompanying security agreements to be recorded, assignments of patents and patent applications are recorded under cover sheets that identify the relevant patent number or application number, ${ }^{145} \mathrm{a}$ public search of assignee records would indicate both the name of the conditional assignee and the particular assets subject to its interest.

A secured party who records a conditional assignment or mortgage with the PTO has the peace-of-mind in knowing that it has placed others on constructive notice of its interest. Subsequent transferees cannot take free of that interest as they may of a security interest. However, a secured party that records a conditional assignment or mortgage in order to give constructive notice of its interests to subsequent purchasers and mortgagees may find that, because it is treated as the owner of an underlying patent or application, it has acquired more rights and obligations than anticipated. A mortgagee or conditional assignee could be liable for infringement claims and be required to sign the following: requests to continue prosecution of an application; requests for status of an application;

141 See Manual of PATEnt EXAmining Procedure, supra note 75, at 300-15.

142 An exception to public availability is made in the case of pending patent applications not published under 35 U.S.C. $\S 122$ (b) (2000).

143 See 37 C.F.R. § 1.12(a)-(b) (2005). See also MANUAL OF PATENT EXAMINING ProcedURE, supra note 75 , at $300-03$.

144 See Manual of PAtent Examining Procedure, supra note 75, at 300-10-11.

145 See 37 C.F.R. $§ 3.21$ (2005). See also MANUAL of PATENT EXAMINING Procedure, supra note 75, at 300-5. 
grants of powers to inspect an application; consents to express abandonment of applications; appointments of agents to prosecute applications; disclaimers; consents to the filing of reissue applications; consents to the correction of inventorship; transmittals; and replies to actions by the PTO. ${ }^{146}$ Typically secured parties are not prepared to, and would shun the duty to, fulfill such obligations and to assume such liabilities.

\section{Federal law may extend to certain subsequent licensees protections from Article 9 similar to those protections extended to subsequent transferees.}

In addition to apparently preempting Article 9's provisions addressing the relationship between secured creditors and subsequent transferees, case law suggests that the Patent Act also preempts state laws regarding the relationship between secured creditors and subsequent licensees. In Rhone-Poulenc Argo, S.A. v. DeKalb Genetics Corp. ${ }^{147}$ ("RPA v. DeKalb"), an en banc panel for the Federal Circuit considered whether Monsanto, as sublicensee of a licensee ("DeKalb") who acquired its license by fraud from Rhone-Poulenc Agro, S.A. ("RPA") was infringing the rights of the patent owner. The district court initially held that Monsanto was a licensee for value entitled to protection by federal common law, ${ }^{148}$ not state law, even though DeKalb acquired its license by fraud. The Federal Circuit panel held that section 261 of the Patent Act did not govern the case because that section applies only to inconsistent assignments by patent

146 MANUAl of PATENT EXAMINING Procedure, supra note 75, at 300-19.

147284 F.3d 1323 (Fed. Cir. 2002).

148 Despite the protestations of Erie Railroad Co. v. Tompkins, 304 U.S. 64, 78 (1938), that there is no federal common law, cases, particularly those dealing with licenses, make it clear that there is some form of federal common law dealing with patents. 
owners, not to situations in which an interest received is voidable. As a result, the Court looked to the question of whether Monsanto had "authority" to use the patent under section 271 of the Patent Act; a question which it said would generally be governed by state law. However, rather than applying federal law (section 261) to govern some bona fide purchaser rules but not others (as in the case of a voidable right), the Court decided that federal law should govern the assignability of a license in the circumstances. ${ }^{149}$

After surveying a wide body of law relating to the rights of purchasers of personal property, the Court concluded that a distinction should be drawn between purchasers who acquire "title" as opposed to other rights, such as licensed or leased rights. ${ }^{150}$ While Monsanto argued that "title" is an antiquainted concept on which to formulate a rule for this purpose, the Court found support for this distinction in recent developments such as the Uniform Computer Information Transactions Act ("UCITA") which was promulgated by NCCUSL in 2000 (although it is not generally viewed as having been a successful legislative effort). The Court cited an official comment to UCITA that generally dismisses as inappropriate the concept of bona fide purchasers for licensees of rights. ${ }^{151}$ As a result, the Court concluded that a subsequent non-exclusive licensee is not entitled to bona fide purchaser protection. ${ }^{152}$ However, in dictum, the Court acknowledged that certain exclusive licensees may be entitled to bona fide purchaser protection: "[O]ur precedent has recognized that in some circumstances an exclusive patent license may be

\footnotetext{
${ }^{149}$ Dekalb, 284 F.3d at 1328-29.

${ }^{150}$ Id. at $1329-31$.

${ }^{151}$ Id. at $1330-34$.

${ }^{152}$ Id. at 1334 .
} 
tantamount to an assignment of title to the patent ....when the licensee holds all substantial rights under the patent.",153

In sum, DeKalb v. RPA provides that federal law will likely govern disputes between secured parties and subsequent licensees. In the case of exclusive licensees, they may not be entitled to a bona fide purchaser defense against title defects of their licensors, but whether a security interest perfected under state law rises to the level of a title defect that could impair the rights obtained by subsequent licensees is an open question. The potential bona fide purchaser rights of subsequent exclusive licensees preserved in dictum in this case presents potentially even greater risks to secured parties. Most frustrating from the perspective of the secured party may be the federal law's pervasive reach into these priority disputes which continues to raise questions of whether any secured party, perfected under state law, can take any action that will be effective under federal law to protect it from potentially fatal flaws in priority disputes with federally recognized and protected rights.

\section{Federal law can preempt state law addressing priorities between the interests of secured parties and prior transferees and licensees.}

Both section 261 and case law support the conclusion that security interests perfected by filing financing statements are generally vulnerable to the interests of subsequent transferees and licensees, but section 261 also suggests a priority rule as between secured parties and prior transferees. While section 261 requires recordation of assignments to prevail over purchasers and mortgagees, it does not address priorities between secured parties and prior unrecorded assignments. In fact, case law suggests that

153284 F.3d at 1314. 
section 261 will not protect all potential interests in patents from the enforceability of prior unrecorded assignments, because its sole purpose is to protect good faith purchasers and mortgagees for value. ${ }^{154}$ As a result, an unrecorded assignment is not necessarily void as against a subsequent security interest that does not constitute a purchase or mortgage. ${ }^{155}$ This means that a secured party may not necessarily rely on the PTO records for the state of title to patent collateral.

To the extent that a secured party is willing to assume the potential liabilities and responsibilities associated with being a conditional assignee or mortgagee and takes its interest for value and without notice, section 261 would make prior assignments, grants and conveyances void as against the secured party unless the prior assignments, grants and conveyances were recorded within three months. A mere secured party, however, may find itself in the position of not being entitled to rely on the federal records. As a result, unless a secured party finds another protective source of law (such as the right to be subrogated to another's interest), the federal records may neither give a secured party a means by which to protect its interest in patents nor reliable comfort about the ownership of its debtor's interest in patents.

\section{The view of secured parties.}

The value attributable to collateral by secured parties and the attendant terms on which credit will be extended depend on the ability of the secured party to realize value

\footnotetext{
154 See Weinar v. Rollform, Inc., 744 F. 2d 797, 807 (Fed. Cir. 1984); Bailey v. Chattem, Inc., 684 F. 2d 386, 392 (6th Cir. 1982); Why Corp. v. Super Ironer Corp., 128 F. 2d 539, 541(6th Cir. 1942); John Tuman \& Sons, Inc. v. Basse, 113 F. 2d 928, 928 (2d Cir. 1940).

155 See supra note 70 and accompanying text.
} 
from the collateral upon default. Any uncertainty regarding the rights of secured parties undermines that value and, so too, the desirability of credit terms available to a debtor. When the collateral is comprised of patents, secured creditors' uncertainty about their rights is exponentially greater than their uncertainty when the collateral is comprised of assets squarely within the ambit of Article 9. Because the Supreme Court denied certiorari in Cybernetic Services, there is no definitive federal law assuring secured creditors, who perfected by filing financing statements, that they would prevail over a bankruptcy trustee. Likewise, while case law suggests that state law would govern disputes between a debtor and a secured creditor and between creditors of a debtor, there is no definitive law on these points.

Most distressing to secured parties is that section 261 of the Patent Act may not provide secured parties with any protections. A security interest perfected by filing a financing statement probably cannot be enforced after patent collateral is transferred to a subsequent purchaser or mortgagee for value and without notice. A secured creditor that perfected by filing could prohibit a debtor from transferring or mortgaging its patents and patent applications, but once the covenant was breached, collateral values could disappear. ${ }^{156}$ A secured party can protect itself by filing a notice of its interest with the PTO, but the efficacy of such a filing is uncertain because even if the filing is effective, its value is limited due to the absence of "floating lien" concepts in federal law.

\footnotetext{
156 Additional issues of concern to secured parties but beyond the scope of this article arise out of the timesensitive nature of much secured lending. Secured creditors often are accustomed to being able to rapidly search current financing statement databases. The PTO's records regarding patents and patent applications are badly outdated. A related issue arising out of the fact that Section 261 permits unrecorded transfers to be effective if filed within three months. As a result, even if the PTO records were current, a creditor could not determine whether there had been an effective transfer of a patent or patent application. See generally, Turner, supra note 118.
} 
Moreover, unlike subsequent purchasers and mortgagees, secured parties are not necessarily entitled to rely on the records of the PTO in order to ascertain whether a debtor has transferred or mortgaged a patent or patent application. Theoretically, a secured party could turn to mortgages and conditional assignments to protect its interests in patents, but any potential value of those devices is undermined by the fact that the security devices fail to provide floating liens and potentially convey unwanted ownership rights and responsibilities.

Under these circumstances, it is understandable why secured creditors substantially discount value attributable to patent collateral or engage in elaborate schemes to isolate patent collateral from competing claims. The first approach reduces available credit to patent owners. The second approach can substantially increase transactional costs without achieving the degree of protection generally provided to secured creditors by Article 9. Neither approach prudently encourages commerce dependent on intellectual property.

\section{The view of patent owners and licensees.}

While generally not well-articulated, the issues facing secured creditors necessarily pose mirror issues for others with interests in patents. For example, to the extent that rational purchasers of patents (particularly when other personal property is also being purchased) would check UCC records for conflicting interests (and so obtain actual knowledge of other interests in those assets), the potential due diligence burden on those with interests in patents could be expanded dramatically beyond what is commonly considered appropriate. The possibility that security interests in general intangibles could encumber all patents owned, not only by the patent owner of record under the Patent Act, 
but also by prior owners, might also come as a surprise to those accustomed to a practice that disregards such state interests. The fact that a secured party's interest could encumber after-acquired patents further expands the issues that must be considered in connection with acquiring patents. Ultimately, owners and licensees of patents will bear the burden of costs and delays attendant to encumbering, acquiring and transferring interests imposed by the uncertain interplay between the UCC and the Patent Act.

It can be argued that the paucity of case law addressing the issues discussed in this article indicates that these problems are not perceived as significant issues in the real world; however, the extent of secondary materials addressing the issues from the perspective of secured parties suggests otherwise. The absence of case law may merely reflect the limited number of cases in which financing is provided on the basis of patent collateral. As consumers of financial services, but not the craftsmen of their structures, patent owners may have been relatively silent about their plight, not for lack of need, but rather for a lack of alternative perspective. However, the louder voices of secured lenders should not be understood to suggest that there are not also other interests deserving attention in this unsettled area of the law.

\section{Difficulties with legislative reform.}

Over the years, the legal professional has wrestled with the question of how to remedy what is generally perceived to be the unsettled state of the law governing security interests in patents. In 1991, Professors Weinberg and Woodward proposed that a federal office be created in which financing statements would be filed to perfect security interests in federal intellectual property. Federal secured transactions laws would 
generally govern perfection of security interests and priority disputes. ${ }^{157}$ Among the problems found with this proposal, in addition to political issues, was that it failed to resolve the problem created for secured creditors by the Patent Act, which permits transfers, which are recorded after they are executed, to relate back to an earlier date. ${ }^{158}$ The efficacy of the proposal also suffered from the fact that perfection of security interests by filing in a federal system would require the creation of an entirely new body of federal law. Secured parties are well-acquainted with the state-based body of law regarding perfection by filing, and the potential for difficult preemption issues lurked beneath the surface of the proposal.

In 1996, after a scholarly review of the area, Professor Haemmerli in Insecurity Interests ${ }^{159}$ proposed the adoption of laws establishing a federal system in which security interests were perfected by federal filing and that the priority of interests between security interests and subsequent transferees was governed by a first-to-file rule, regardless of notice of prior interests. The proposal would have given much needed certainty to the area of security interests in patents while avoiding the relation-back problem remaining under the earlier proposal by Professors Weinberg and Woodward. However, the proposal left secured creditors' concerns about the feasibility of implementing an entire body of federal law that would mesh seamlessly with Article 9 unanswered.

\footnotetext{
157 See Harold R. Weinberg \& William J. Woodward, Jr., EasingTtransfer and Security Interest Transactions in Intellectual Property: An Agenda for Reform, 79 KY. L.J. 61 (1991).

158 See Haemmerli, supra note 39 at 1724.

159 See id. at 1670.
} 
In 1999, after years of study, ${ }^{160}$ the Section of Intellectual Property Law and the Section of Business Law of the American Bar Association proposed a Federal Intellectual Property Security Act ("FIPSA"). Under FIPSA, a secured party would make a federal filing to establish the priority of its lien "with respect to subsequent bona fide purchasers for value and all other subsequent transferees of ownership interests, excepting only security interests. Recordation of security interests in all intellectual property in the relevant state agency under Article 9 of the Uniform Commercial Code would perfect the security interest and establish priority as against other secured parties and lien creditors." ${ }^{161}$ In other words, security interests in patents generally would be governed by state law, but federal filing would be necessary in respect to ownership interests and transfers. FIPSA would also have amended the Patent $\mathrm{Act}^{162}$ to address the relation-back problem and would have permitted federally filed financing statements to apply to after acquired collateral. To accomplish all of this, FIPSA proposed that the Patent Act be amended to permit recording of a document such as a financing statement that could be assigned, that was effective for a limited period of time, that could be continued for additional periods of time, much like a state financing statement, and that a secured party would be required to release when federal intellectual property was no longer collateral. Because FIPSA attempted to address several forms of federal intellectual property concurrently, it also addressed problems potentially not of concern to parties secured by

160 Id. at $1725-27$.

161 Oversight Hearing on Intellectual Property Security Registration Before the House Comm. on the Judiciary, Subcomm. On Courts and Intellectual Prop. (June 24, 1999) (joint statement of G. Larry Engel, ABA Section of Bus. Law and Susan Barbieri Montgomery, ABA Section of Intellectual Prop. Law), available at 1999 WL 430288 [hereinafter Statement].

162 See American Bar Association Section of Intellectual Property Law, Federal Intellectual Property Security Act, available at http://www.abanet.org/intelprop/106legis/fipsa.html. 
patents. For example, FIPSA was intended to clarify that security interests in patent proceeds do not require federal filing in order to be perfected. ${ }^{163}$ A federal database relating to security interests searchable by the debtor would have to be maintained. The PTO, Registrar of Copyrights and Plant Variety Protection Office were encouraged to coordinate their procedures so that federal intellectual property would be similarly treated. FIPSA's proposals were both breathtakingly sweeping and fruitless.

At the same time that FIPSA was proposed, the Commercial Finance Association ("CFA") made a modest proposal. Under the CFA's interim proposal, the Copyright Act would have been only modestly amended to permit perfection of security interests under Article 9, with transfers being governed by federal law. ${ }^{164}$ This proposal would have codified Cybernetic Services, but would not have resolved any of the other problems facing parties concerned with financings secured by patents. A slightly more aggressive version of the CFA's proposal was subsequently proposed that, in addition to addressing Cybernetic Services, would have permitted secured parties to perfect their security interests under state law, but would have required them to make federal filings to achieve priority over subsequent good faith mortgagees and transferees for value. ${ }^{165}$ While their modest scope made these two proposals potentially more feasible to accomplish than some of the earlier proposals, their modesty also limited their efficacy, leaving unaddressed the absence of a floating lien concept in federal law.

All of these proposals would finally have settled, without need for further

\footnotetext{
163 See Statement, supra note 154 at 5.

164 See generally, Ara A. Babain, Striving for Perfection: The Reform Proposals for Copyright-Secured Financing, 33 LOY. L.A. L. REV. 1205, 1210 (2000).

165 See Turner, supra note 118 at 13.
} 
litigation, the question addressed by Cybernetic Services - whether a secured party who perfects its security interest by filing a financing statement in state records has priority over the interests of a bankruptcy trustee. Some of the proposals would also have addressed other issues facing secured parties today, but for many reasons, these efforts by the legal profession have been unsuccessful.

\section{Changes without legislative reform.}

As discussed above, federal patent law already defers to Article 9 on a number of issues of importance to secured parties. For example, a security interest perfected under state law has priority over the hypothetical lien creditor status of a bankruptcy trustee. Also, state law governs disputes between debtors and secured parties, between secured parties of the same debtor, and between secured parties and other lienors (other than mortgagees and similar parties) of the same debtor. While less clear, it is also possible that secured parties who file notice of their security interests with the PTO can achieve priority over subsequent transferees and licensees. That secured parties already can perfect a wide array of rights illustrates that the inability to accommodate recordation of effective notices of "floating liens" is a failure of the recording system and not a requirement of federal law. The only obvious statutorily mandated issue facing secured creditors today is embedded in the three-month recording grace period given to transferees of patents.

With the foregoing in mind, it would seem that modern case law is not entirely lacking in grounds on which to build a law of secured transactions in patents. Security interests in patents, though, will not be the predictable sources of value to secured creditors needed to facilitate commerce in the area until the implications scattered in 
large bodies of case law are pulled together in a coherent fashion. Presently, federal regulations merely confirm that federal law takes no position on the effect of security interests, but the absence of federal determination does not indicate an absence of authority in federal law to make necessary determinations.

Section 317.03 of the Manual of Patent Examining Procedures indicates that even recordation of documents such as patent assignments is not determinative of their effect:

The recording of a document pursuant to $\S 3.11$ is not a determination by the Office of the validity of the document or the effect that document has on the title to an application, a patent, or a registration. When necessary, the Office will determine what effect a document has, including whether a party has the authority to take an action in a matter pending before the Office.

Neither the Patent Office nor any implementing regulations specify required formats for assignments or many other recordable documents relating to patents, but procedures exist for addressing the effect of those documents when necessary, even when the effectiveness of those documents is, as is often the case, dependent on state, not federal, law.

The problem with the current federal regulatory apparatus dealing with security interests in patents is founded on the distinction drawn between assignments and licenses. Section 301 of the Manual of Patent Examining Procedures establishes the distinction between license and assignments is that an assignment "in general, is the act of transferring to another the ownership of one's property, i.e., the interest and rights to the property." In 37 CFR $\S 3.1$, assignment of patent rights is defined as "a transfer by a party of all or part of its right, title and interest in a patent or patent application...." An assignment of a patent, or patent application, is the transfer to another of a party's entire 
ownership interest or a percentage of that party's ownership interest in the patent or application. ${ }^{166}$ In order for an assignment to take place, the transfer to another must include the entirety of the bundle of rights that is associated with the ownership interest, i.e., all of the bundle of rights that are inherent in the right, title and interest in the patent or patent application. ${ }^{167}$

In contrast, the Manual of Patent Examining Procedures defines a "license" as:

$[T]$ he licensing of a patent transfers a bundle of rights which is less than the entire ownership interest, e.g., rights that may be limited as to time, geographical area, or field of use. A patent license is, in effect, a contractual agreement that the patent owner will not sue the licensee for patent infringement if the licensee makes, uses, offers for sale, sells, or imports the claimed invention, as long as the licensee fulfills its obligations and operates within the bounds delineated by the license agreement.

The fact that a security interest empowers the secured party to effect an "assignment" by transferring all of a debtor's rights in a patent pursuant to section 9-617 of the UCC puts security interests squarely between a current assignment and a license. The federal recording system is indifferent to interests such as licenses not involving disposition of ownership interests in patents, even though these interests are integral to the rights of assignees and purchasers of patents at UCC foreclosure sales. The current legal limitations on security interests in patents not only hampers secured parties in the analysis of their rights, but it hampers assignees of patents. Assignees face the question of whether their interest may be subject to the rights of a secured party of whose interest the assignee knew or should have known existed. This standard is generally met when an

\footnotetext{
${ }^{166}$ See 37 C.F.R. § 3.1 (2004).

167 See 37 C.F.R. $\$ 3.73$ (2004).
} 
assignee actually files the security interest with the PTO or by application of a reasonable assumption that an assignee would search state UCC records and, as a result, learn of the security interest. These ambiguities in rights potentially adversely affect the value of patents, if only by increasing transactional costs incurred to limit risks.

Unlike a license, the contingent right to transfer ownership of patents is inherent in the nature of a security interest. Accordingly, ownership interests are included in the federal record. To the extent that the federal record can be construed to give third parties constructive notice of a contingent right to transfer patents by reason of recording with the PTO, patent owners would be more readily able to borrow against the value of their property. At the same time, assignees could benefit from federal regulations establishing when they are on notice of a prior security interest that could potentially eliminate their interest in patents.

\section{Conclusion.}

The viability of commercial transactions involving patents and patent applications could be enhanced by modest revisions in regulations that have been built on the unsound principle that security interests are the equivalent of licenses. If the regulations acknowledged that security interests recorded with the PTO give constructive notice of the rights of secured parties, secured parties and transferees would have some greater certainty about their respective rights in patents. But mere regulatory change would not do justice to these transactions. The grace period for filing assignments would continue to plague secured transactions, as would the absence of a mechanism for establishing a floating lien and other ambiguities about conflicting interests..

Of course, the wheels have not ground to a halt over these problems, but the difficulties that they have imposed on structuring commercial transactions has taken 
an untold toll. Not all transactions can justify the legal costs associated with working through potential issues among interested parties or the delicate balancing act required appropriately to allocate risks attendant to the issues among those parties. Theoretically, purchasers of patents and patent applications may be acquiring their interests subject to the license-like security interests created by prior owners in favor secured parties perfected by filing in local jurisdictions, but, as a practical matter, parties probably seldom undertake the research necessary to deal with such prior interests. (In other words, the risk attendant to such security interests is probably usually shouldered by transferees.) On the other hand, owners of patents find their ability to leverage based on the value of those patents limited, because the value is discounted by credit providers based on legal uncertainties as to applicable perfection, priority and foreclosure methodologies. (The patent owners almost assuredly bear the resulting burden.)

In sum, issues surrounding security interests in patents and patent applications, which are usually thought to be of concern almost exclusively to secured parties, are perhaps even more legitimate areas of concern for the owners of patents and patent applications, the very people whom federal patent law has an interest in protecting. Uniform state laws containing a series of well-established rules, augmented over time by case law, have established precedents from which patent owners could benefit through modest changes in federal law appropriately acknowledging the nature of a security interest and implementing changes meeting commercial expectations for simplicity (such as in filing mechanics), efficiency (such as floating liens) and predictability (such as the priority of security interests over other claims). The changes required are modest, because, for the most part, federal law could accomplish these ends by deferring to state 
law.

To the extent that one of the goals of federal patent law is to protect the rights of owners of patents and that those interests could be furthered by carefully crafted changes in federal law deferring to state law, only a limited number issues (such as how to accommodate floating liens and eliminate the retroactive effective of recording transfers) remain open for debate. Given the benefit anticipated from addressing these open issues, failure to do so seems difficult to in light of the importance of intellectual property in a modern economy. As noted in the PTO's website: “The strength and vitality of the U.S. economy depends directly on effective mechanisms that protect new ideas and investments in innovation and creativity."168

168 http://www.uspto.gov/web/menu/intro.html 